\title{
GPSセンサネットワークを用いた表層流観測システムの開発と 海水浴場への適用
}

\author{
Development of Surface Current Observation System using GPS Sensor Network \\ and its Application to a Bathing Beach
}

\author{
芝田 浩 $^{1}$. 岡辺拓巳 ${ }^{2}$. 石川仁憲 ${ }^{3}$. 堀口敬洋 ${ }^{4}$. 青木伸 ${ }^{5}$. 小峯 力 $^{6}$ \\ Hiroshi SHIBATA, Takumi OKABE, Toshinori ISHIKAWA, Takahiro HORIGUCHI \\ Shin-ichi AOKI and Tsutomu KOMINE
}

\begin{abstract}
The authors developed a new observation system to visualize the present status of the surface current in a bathing beach area, which utilizes GPS sensor floats and a network system that connects multiple sensors. This system can detect a real time trajectory and flow velocity of the GPS sensor floats to a computer, and can display the data on the screen. In this paper, the specification of the system and the results of its application to a bathing beach are described. In the observation, the GPS sensor floats and a person having a GPS sensor were floated together and compared.
\end{abstract}

\section{1. はじめに}

日本の夏季には, 海水浴, サーフィン, 釣り等, 多く のマリンレジャーが親しまれており, 特に沿岸域は海域 利用者の㮩いの場となり多くの利用者がいる. それ故に, 沿岸海域での海浜事故が多発しており, 時には尊い命が 失われることも少なくない状況である. 海上保安庁の海 難事故統計によると, 平成 23 年には 1766 名が海浜事故等 に遭遇しており, 事故内容の内訳としては遊泳中が266名, さらにその内死者・行方不明者数は91名であった（海上 保安庁, 2012a ; 海上保安庁, 2012b). これに対して, 海 浜事故を未然に防ぐための活動も盛んに行われており, 全国各地の海水浴場やプール等では, 事故防止のための 監視や指導, 救助等のライフセービング活動が盛んに行 われている.ライフセーバーが活躍する約 200 海岸におけ る統計情報によると, 毎年約 2000 件もの救助が行われて いる (小峯 他, 2009). 今後, 沿岸海域のマリンレジャ 一による観光産業, レジャー産業の拡大を推進するため には, 海浜を利用する上での安全性の確保が必要となる. 特に, 遊泳中の事故の多くは, 遊泳禁止海域や離岸流な どの海浜流が存在する場所で多く発生していること，ま た, 事故者の約 4 割がこれからの社会を支える 18 歳以下 の若年齢層であることから, 早急の事故防止対策をとる

\begin{tabular}{|c|c|c|}
\hline 1 & 修(工) & $\begin{array}{l}\text { 広島商船高等専門学校講師 } \\
\text { 電子制御工学科 }\end{array}$ \\
\hline 2 正会員 & 博 (工) & $\begin{array}{l}\text { 豊橋技術科学大学研究員 } \\
\text { 工学部建築·都市システム学系 }\end{array}$ \\
\hline 3 正会員 & 工修 & $\begin{array}{l}\text { (一般財団) 士木研究センター } \\
\text { なぎさ総合研究室 }\end{array}$ \\
\hline 4 正会員 & & (株) クレアリア海岸部 \\
\hline 5 正会員 & 工博 & 大阪大学大学院教授地球総合工学専攻 \\
\hline 6 正会員 & 修(体) & 流通経済大学教授スポーツ健康科学部 \\
\hline
\end{tabular}

必要がある. 海水浴場で発生する海浜事故では様々な要 因が考えられるが，その中でも人間が流される過程に対 して表層近くを流れる海浜流が影響していると考えられ ている。しかし, 沿岸海域における代表的な表層流とし て挙げられる離岸流, 沿岸流などに対して既往の研究で は, 染料やハンディ GPSを乗せたフロートのトレーサー による調査 (西他, 2004) や, 計測機器による流況観測 （出口 他，2006）等の方法によって研究されているが, いまだ未知な点が多い現象である. そのため, 沿岸海域 における海浜流の発生やその動態を明確に検知すること は重要であり, 海浜を安全で快適に利用するためには必 要不可欠である（青木他, 2008 ; 石川他, 2011).

一方，近年無線通信技術やセンシング技術の発展に伴 い, 情報を効率よく収集するための手段として, 無線セ ンサネットワークが注目されている(Akyildiz 他, 2002). 一般的に無線センサネットワークでは，センサを搭載す る無線の端末（以下，センサノード）を空間に散在させ， 互いに協調しデー夕を採取することで, その領域の状況 や環境を把握する（図-1）.1つのセンサノードあたりの 能力は非常に限られたものであるものの，ネットワーク 全体で環境観測に対して機能を発揮するシステムを構築 することができる。本研究では, 複雑な条件が関連して いる沿岸海域の表層流の観測に対して, GPSセンサを搭 載したセンサノードで形成される無線センサネットワー クを用いた観測システムの適用について検討した。ここ では海水浴場での実際の利用を念頭に入れており, 本シ ステムを使用することで観測から結果を確認するまでを リアルタイムに処理できる，表層流の観測に対する無線 センサネットワークの適用方法, 実際に開発したシステ ムの構成及び，実現した機能について述べる．さらに， 


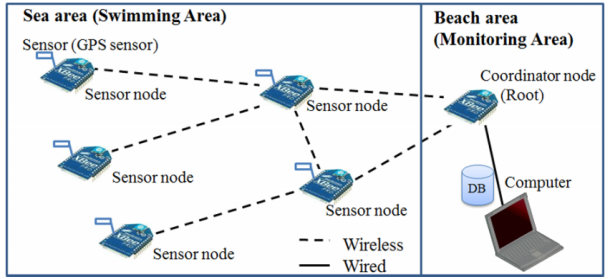

図-1センサネットワークの概要図

システムの動作と実際の利用に対する確認のために実施 した，2011年夏期の相良海岸（さがらサンビーチ）にお ける実海域での観測とその結果から，実際の利用に対し て考察した.

\section{2. 表層流の観測とセンサネットワークの利用}

海浜事故につながる表層流について，既往の研究にお いて様々な方法で観測が試みられている。しかし，海の 状況 (海水温, 流向流速など), 風向風速, 気象条件 (気 温, 気圧), 地形など複雑な条件が関連して発生するため, 期待する現象を観測するのが難しい。さらに，一般的な 流向流速などの計測機器を使用した観測では, 解析が完 了するまでをリアルタイムに処理することが難しいこと から，海水浴の安全利用への適用に対しては，さらなる 研究開発を必要としている。本研究では，センサネット ワークを利用し，対象海域に放ったセンサノードが互い に協調しデー夕を採取することで，流況を把握する.

本観測システムでは，GPSを組み込んだセンサノード を搭載したフロート（以後，GPSフロートと呼ぶ）を観 測域の波打ち際に多数放ち，表層流や風の影響により自 由に移動できるような状態にする，GPSフロート上のセ ンサノードは，センサネットワークを形成することによ り相互接続し協調してデータを観測することができる. センサノードは，GPSセンサで取得した信号から現時点 での位置情報を一定間隔で求め，センサネットワークを 経由してコンピュータへ送信する．ユーザは，コンピュ ータの画面上で, その位置データをリアルタイムに一括 で取得することで，GPS フロートが移動する軌跡を確認 することができる．さらに，得られたデー夕から移動速 度を求めることで，海域の表層流を把握する（図-2).

\section{3. システム構成}

海水浴場における表層流の観測システムの概要を図-3 に示す。フロートGPSフロートには，GPSセンサを搭載 したセンサノードを乗せている，センサノードは，GPS センサ，マイコンボード，センサネットワークを形成す るための通信デバイスから成る.GPSセンサで取得した 人工衛星からの信号により現時点での位置情報を求め る。さらにセンサノードは，搭載した通信デバイス

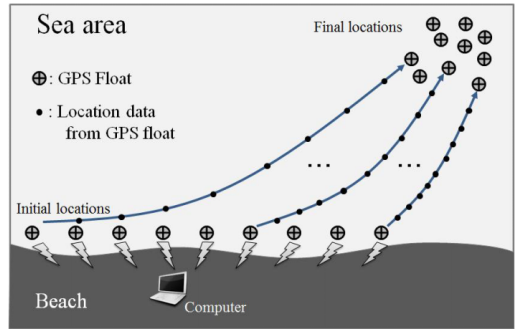

図-2＼cjkstart表層流観測システムの概要図

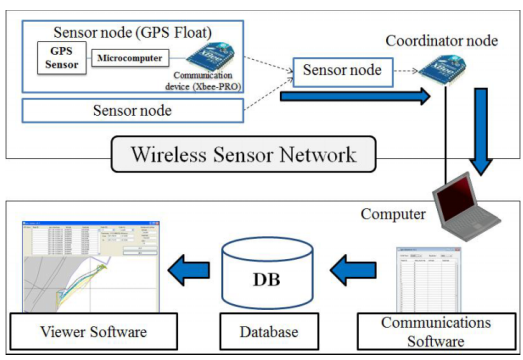

図-3 システム構成

(xbee）により無線センサネットワークを形成しており， 求めた位置情報をネットワーク内に位置する唯一のコン ピュータヘ一定間隔で送信し続ける（Digi International, 2011）。以上のGPSセンサによる位置情報の取得，及び 通信デバイスによる情報の送信などの処理をマイコンボ ードで制御する.

一方コンピュー夕内部では, 各GPS フロートからの位 置情報をリアルタイムに受信し，その情報を用いて接続 されたコンピュータでデータ表示のための処理を行う. コンピュータ内部では, 通信ソフトウェアにより観測デ ータを受信し内蔵のデータベース（以下，DB）へ格納す る．得られたデータは，すべてDBで管理する，ユーザ は，DBに格納されたデー夕を確認するために，コンピ ユータ上のデータ表示ソフトウェアを使用する。データ 表示ソフトウェアでは, DBから検索条件に合致したデ ー夕を検索し表示するとともに，簡易的な地図上にプロ ットする（図-4）。地図情報は，国土交通省国土地理院 （1998）のデータを使用した。このようにして受信した 各時刻における位置情報から表層流の軌跡をリアルタイ ムに得ることができる。

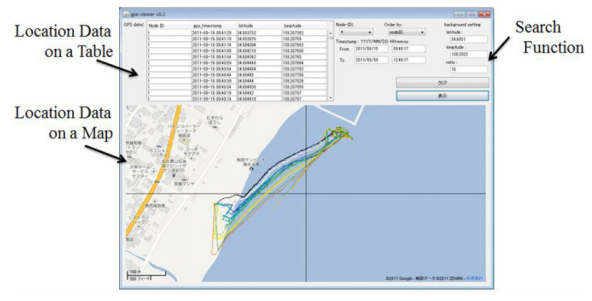

図-4 システムのデータ表示画面 

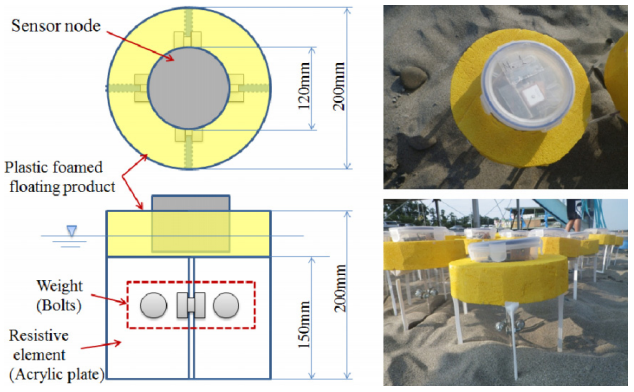

図-5 GPS フロートの形状

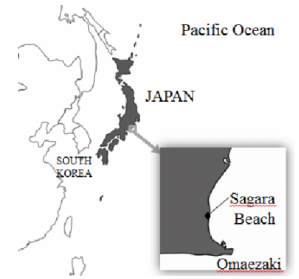

(a) 日本近海

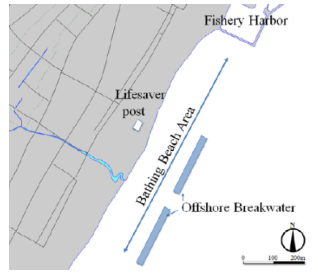

(b) さがらサンビーチ
図-6 観測方法

GPS フロートの形状を図-5に示すＧPS センサは，人 工衛星からの信号を受信しやすいことと，海の表層を人 間が流される場合に近い移動の仕方をするように考慮し 設計した。センサ端末の容器を取り囲むように発泡素材 の浮きを配置し，GPS センサが海水面より上に出るよう にした。ささら，表層の流れに追従するように，アクリ ルの抵抗体を十字に設置し, 波による動摇に対して安定 するようにボルトのおもりを設置した．ボルトの設置場 所としては, 人間の重心に近くなるように, GPS フロー トの中心近くに配置した.

\section{4. 観測の概要}

\section{(1) 対象海岸}

静岡県相良海岸において, 海水浴場として遊泳区域が 指定されているさがらサンビーチ（図-6）を調査対象海 岸とした。相良海岸は御前崎から約 $10 \mathrm{~km}$ 北方に位置し て駿河湾に面しており，卓越風向は西～南西，卓越波向 は東〜南東である. 同海水浴場は相良港〜離岸堤背後を 遊泳エリアとしており，相良港防波堤沿いや離岸堤間に おいて離岸流の発生が報告されている。 また，7〜8月の 2 ケ月間，ライフセーバー（相良ライフセービングクラ ブ）が常駐して利用者の安全を確保している.

\section{(2) 観測方法}

本システムを使用した現地観測は，下記のa）からd） までの手順にて実施した（図-7）.

a) GPS フロートを持った人員（25個の GPS フロート を使用し 13 名の人員で実施）が，波打ち際に整列 する。

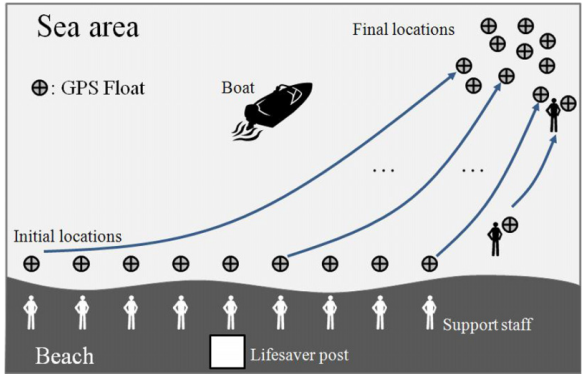

図-7 観測方法

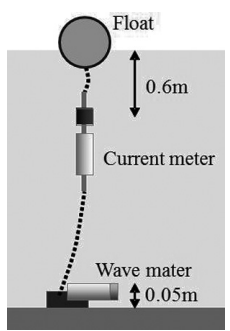

図-8 計測機器設置の概要

表-1 計測機器

\begin{tabular}{c|c}
\hline 観測項目 & 型名 (メーカー) \\
\hline 流速 & Infinity-EM (JFEアドバンテック) \\
\hline 波高 & Compact-WH (アレック電子) \\
\hline
\end{tabular}

b）腰の高さまで入水後, 監視所からの合図により GPSフロートを海上に放つ。

c）海上を浮遊している GPS フロートからの位置デー 夕を，監視所にあるコンピュータでセンサネット ワーク経由により一括で受信する.

d）一定海域に到達したところで，ボートを使用して 人手により GPS フロートを回収する。

また，上記の手順b）以降において，GPSフロートと 共にGPSノードを持った人間も同時刻に漂流した。人間 は, 浮き輪の内側につかまり, 足を海底に向けて下げて いる状態で漂流した. GPS フロートの観測值と実際の人 間の漂流との相関について観測した.

さらに，GPS フロートによる観測を実施した同じ時間 帯に, 計測機器を設置した（図-8, 表-1）。1基目離岸堤 の背後付近の砕波点の沖側に設置した（北緯 34 度 40 分 55.1 秒, 東経 138 度 12 分 21.0 秒). 計測機器の流速計は水 面下 $0.6 \mathrm{~m}$, 波高計は海底から $0.05 \mathrm{~m}$ の高さにセンサが位 置するよう設置した。

\section{5. 観測結果}

\section{（1）風向風速と潮位}

観測は，2011年8月16日 17:04から 17:57にかけて行な った. 天候は晴れ，4〜6mの西寄りの風が常に吹き，太 


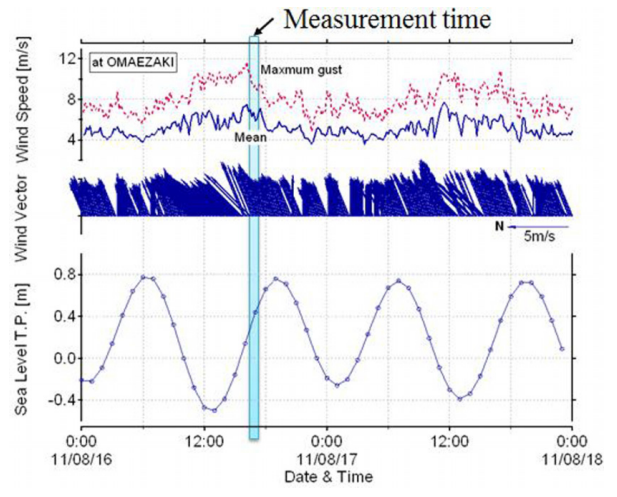

図-9 気象と潮位

平洋高気圧が張り出した気温の高い（日中の最高気温は 30 度以上）真夏日であった。御前崎（気象庁発表）にお ける風向風速および潮位の平時変化を図-9に示す。観測 を実施した時間帯には， $5 \mathrm{~m} / \mathrm{s}$ を越える南西からの風が発 生していた.

\section{（2）計測機器による波浪・流況の観測結果}

計測機器における観測時の有義波高および有義波周期 を表-2に示す。観測時は静穏であった。また，計測機器 を使用した流速のデータについては，波浪の影響を除去 するため有義波周期とほぼ同じ $\mathrm{t}=8 \mathrm{~s}$ で移動平均するとと もに，南北成分と東西成分を位相面にプロットした。そ の結果を図-10に示す。このように流速のデータから流 向は, 北東方向へ向かう成分が卓越していた.

\section{（3）GPS フロートによる観測結果}

今回の観測では, GPS フロートが波や風によりその機 能の実行を妨げられることもなく，位置情報を取得する ことができた，その結果，各GPSフロートが移動する際 の軌跡をデータとして観測することができた．各GPS フ ロートから得られた位置情報を地図上へ時系列にプロッ

トした結果を図-11に示す。遊泳区域付近の初期位置か ら，遊泳区域外の防波堤付近へGPS フロートが移動する 軌跡を確認することができる.

また, GPS フロートの位置情報から平均の移動速度を 求め, 地図上に表示した結果を図-12に示す.四角でマ ークしたのが計測機器の設置場所である. 本図より, GPS フロートの位置によって平均移動速度が異なってい ることがわかり，海岸の南寄りに位置していたGPSフロ 一トほど速度が速くなっていた．さらに，人間の漂流と GPS フロートの平均移動速度を比較すると, 概ね GPS フ ロートの方が 0.1 から $0.2 \mathrm{~m} / \mathrm{s}$ 程度速い結果となった.

今回の観測では，その期間中の気象および海流の流れ は穏やかであり，定常的な表層の流れの観測にとどまり， 急激な沖向きの流れを伴うような危険な流れを観測する ことはなかった.
表-2 有義波高および有義波周期

\begin{tabular}{c|c}
\hline 項目 & 值 \\
\hline 有義波高 & $0.29 \mathrm{~m}$ \\
\hline 有義波周期 & $\mathrm{t}=8.66 \mathrm{~s}$ \\
\hline
\end{tabular}

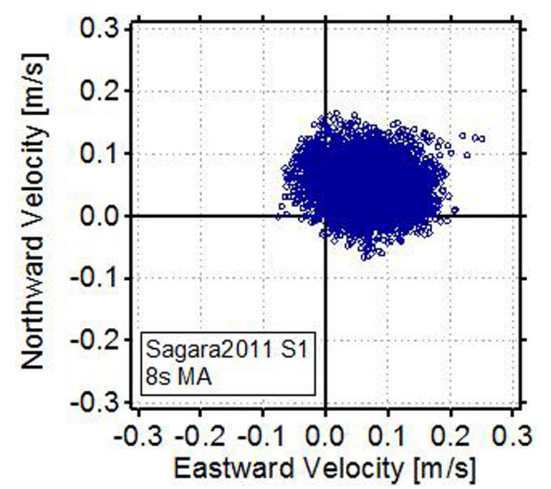

図-10 計測機器による流況の観測結果

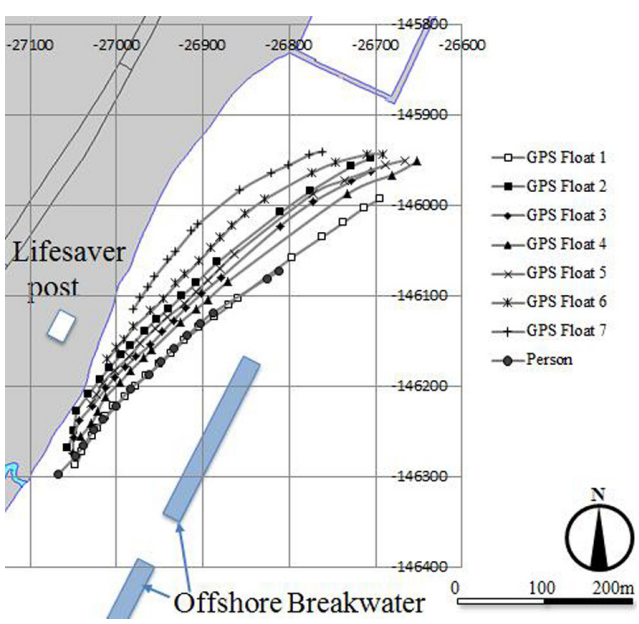

図-11 GPS センサが移動した軌跡

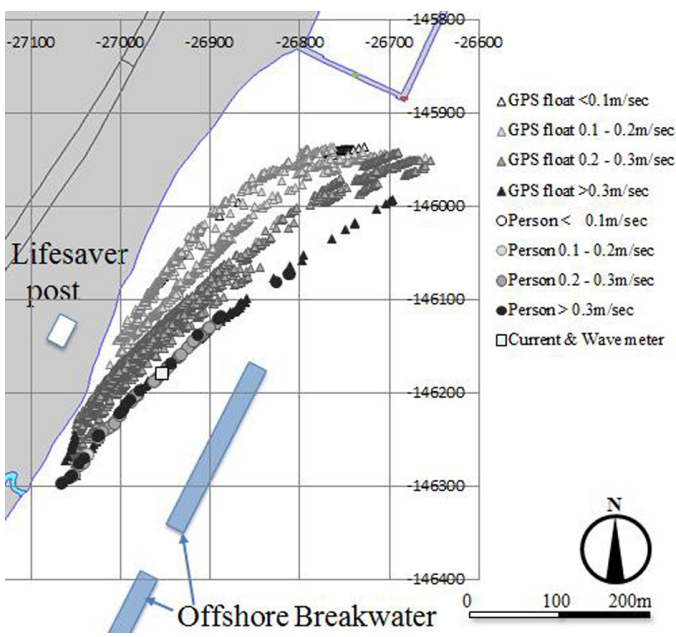

図-12 GPS ンサの平均移動速度 


\section{6. システムを使用した観測と実利用へ向けた考察}

\section{（1）GPS フロートによる観測と人間の漂流について}

今回の観測では，GPS フロートの位置情報から移動す る際の軌跡をデータとして観測することができ，海水浴 場の流況を観測することができた，GPSフロートの移動 とシステムでの軌跡のデータは, 一致していた。ささらに, 本システムを利用した観測結果と，同時刻に設置した計 測機器のデータを比較すると, GPS フロートの移動方向 と, 計測機器のデータから得られた流速の卓越している 方向は, 一致している．ただし，流速の最大值は，GPS フロートの方が概ね 0.1 から $0.2 \mathrm{~m} / \mathrm{s}$ 程度速い結果となって いる。これは, 風の影響を受けているためと考えられ, 観測時に卓越していた風向とGPS フロートの移動方向 が，一致していることからもわかる。これらのことから， 本システムでは，表層の流況を観測することができたと 考える.

またGPSフロートと人間が漂流する際の平均移動速度 を比較すると, 人間の方が 0.1 から $0.2 \mathrm{~m} / \mathrm{s}$ 程度遅い結果と なっているものの, 同様の軌跡を描いている，その原因 としては，水中にある体積及び形状による流れに対する 抵抗の違いが関連しているものと考えられる. そのため, 人間の形状と同じような流体力学的特性を持つGPS フロ ートの形状にする必要がある。

\section{（2）GPS フロートのネットワーク接続について}

本システムを使用することで，観測デー夕を取得でき たが，観測結果（図-11，図-12）を再度確認すると，デ ー夕が密に得られている箇所と疎になっている箇所があ る.これは, GPSフロートからの通信が輻輳状態になり コンピュータまで届かない状態になっていたことが考え られる. 改善方法としては, 通信デバイス内のファーム ウェアを変更し, センサネットワークのネットワークト ポロジーをメッシュ状にすることで, ネットワーク内で のデータの消失を少なくすることが挙げられる．観測精 度をより高めるためには，このような情報の欠損を無く すためのシステム改善が必要である.

\section{（3）システムの操作性改善と実利用について}

本システムの操作性を改善，表示プログラムの画面上 で，各デー夕表示，地図上へのプロットとともに，各地 点での平均移動速度を表示する機能，GPS フロート自体 の操作性（スイッチ, 電池交換方法等）を改善すること, モバイル環境（携帯電話，スマートフォン等）での確認 機能が必要であると考えている。これにより, 海水浴場 での観測を，ライフセーバーや一般の方が容易に操作す ることができ，日々の業務やアクティビティとして流況 の確認方法として活用できる。ささらに，そこで観測され たデータにより，沿岸流の解析への貢献も期待される。

\section{7. 結論}

本研究では, 複雑な条件が関連している沿岸海域の表 層流の観測に対して，GPSセンサを活用した無線センサ ネットワークを用いた観測システムを開発することがで きた．本システムでは，海水浴場での実際の利用を考え， 観測から結果を確認するまでをリアルタイムに処理し， 視覚的に流れを表示できる機能を実装することができ た。さらに，2011年夏期の相良海岸（さがらサンビーチ） における現地観測では, 本システムの多数のGPSフロー 卜を使用することで海水浴場の平面的な流れをリアルタ イムに観測できることを確認した。これにより，海岸の 波動場の状況把握による安全な海岸利用の直接的な評価 ができるとともに，海浜での溺水事故の防止における実 際の海水浴場で利用できるシステム実現の可能性を確認 することができた。

今後は, GPS フロートの形状や操作性の改善により, 観測精度の向上や，ライフセーバーにおける海水浴場の 流況の確認に対する本システムの利用を検討する。これ により，本システムが海水浴場の安全利用に対して貢献 することが期待される.

謝辞：本研究では，現地観測にあたって相良サーフライ フセービングクラブのご協力をいただいた。ここに記し て謝意を表する。

\section{参 考 文 献}

青木伸一・上野成三・西 隆一郎 - 小峯 力 $\cdot$ 石川仁憲 $\cdot$ 堀口 敬洋（2008）：海岸の安全利用からみた静穏時離岸流の現 地調查一研究者,実務者と海岸利用者との連携の試み一, 海 洋開発論文集，Vol. 24，pp. 255-260。

石川仁憲 • 岡辺拓巳・堀口敬洋・青木伸一（2011）：静岡県相 良海岸における静穏時の離岸流発生特, 土木学会論文集 B3 (海洋開発) Vol. 67, No. 2, pp. 679-684.

海上保安庁 (2012a)：海上保安統計年報，第62 巻，pp. 39-41. 海上保安庁 (2012b)：海難の現況と対策について（平成23年 版), p. 28.

国土交通省国土地理院（1998）：数值地図2500（空間デー夕基 盤）静岡-1，CD-ROM.

小峯 力・石川仁憲 ·風間隆宏・堀口敬洋 (2009)：海浜にお ける水難事故の発生要因と予防策, 海洋開発論文集, Vol. 25 , pp. $1335-1340$.

西 隆一郎 - 山口 博 - 岩淵 洋 - 木村信介 - 村井弥亮 - 徳永 企世志・古賀幸夫（2004）：宮崎県青島海岸での離岸流観 測 - 水難事故予防のために一，海岸工学論文集，Vol. 51, pp. $151-155$.

出口一郎・吉井 匠・野村尚生・荒木進歩（2006）：離岸流の 時間変動特性について, 海岸工学論文集, Vol. 53, pp. $101-105$.

Akyildiz. I. F., W. Su, Y. Sankarasubramaniam and E. Cayirci. (2002) : A survey on sensor network, IEEE Communications Magazine, Vol.40, No.8, pp. 102-114.

Digi International (2011) : XBee/XBee-PRO ZB RF Modules, 138 p. 